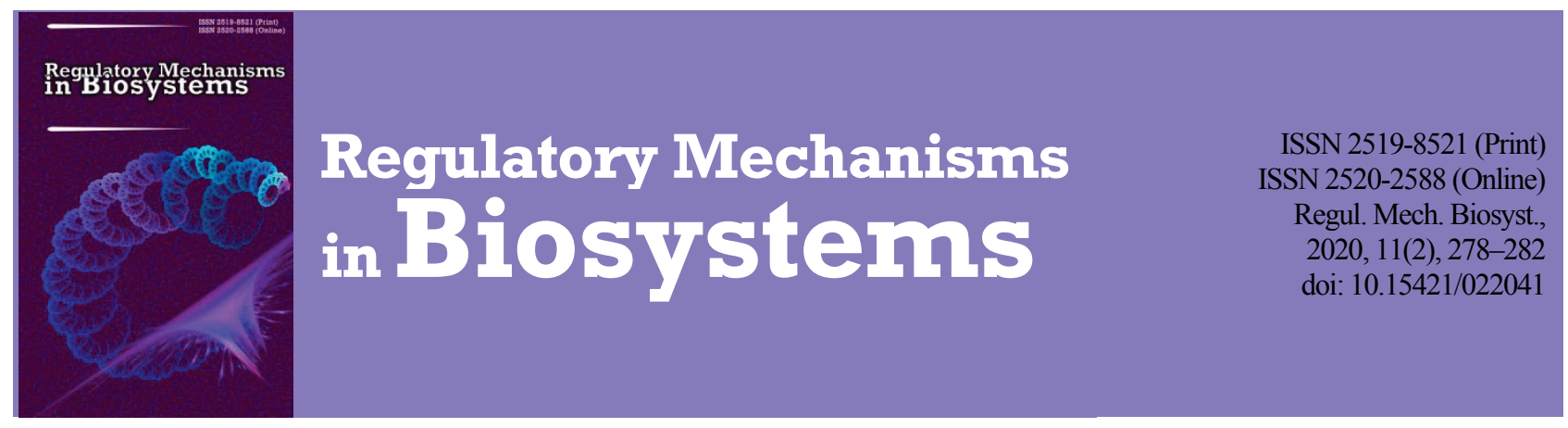

\title{
Reduction of perchlorate ions by the sulfate-reducing bacteria Desulfotomaculum sp. and Desulfovibrio desulfuricans
}

\author{
N. S. Verkholiak, T. B. Peretyatko, A. A. Halushka \\ Ivan Franko National University of Lviv, Lviv, Ukraine
}

Article info

Received 07.04.2020

Received in revised form 02.05 .2020

Accepted 03.05.2020

Ivan Franko National University of Lviv, Hrushevsky st., 4 , Lviv, 79005, Ukraine

Tel.: +38-032-239-40-53.

E-mail:

nataljaverkholjak@

gmail.com
Verkholiak, N. S., Peretyatko, T. B., \& Halushka, A. A. (2020). Reduction of perchlorate ions by the sulfate-reducing bacteria Desulfotomaculum sp. and Desulfovibrio desulfuricans. Regulatory Mechanisms in Biosystems, 11(2), 278-282. doi:10.15421/022041

The usage of microorganisms to clean the environment from xenobiotics, in particular chlorine-containing ones, is a promising method of detoxifying the contaminated environment. Sulfate-reducing bacteria Desulfovibrio desulfuricans Ya-11, isolated from Yavoriv Lake, and Desulfotomaculum AR1, isolated from the Lviv sewage treatment system, are able to grow under conditions of environmental contamination by aromatic compounds and chlorine-containing substances. Due to their high redox potential, chlorate and perchlorate ions can be ideal electron acceptors for the metabolism of microorganisms. To test the growth of the tested microorganisms under the influence of perchlorate ions, bacteria were cultured in modified Postgate $\mathrm{C}$ medium with $\mathrm{ClO}_{4}^{-}$. Biomass was determined turbidimetrically, the content of sulfate ions and hydrogen sulfide - photoelectrocolorimetrically, the content of perchlorate ions - permanganatometrically. The study of the ability of sulfate-reducing bacteria Desulfotomaculum AR1 and D. desulfuricans Ya-11 to grow in a medium with perchlorate ions as electron acceptors showed the inhibitory effect of $\mathrm{ClO}_{4}^{-}$on sulfate ion reduction by bacteria. Bacteria Desulfotomaculum AR1 and D. desulfuricans Ya-11 are able to grow in environments with aromatic hydrocarbons, in particular toluene. The possibility of the growth of sulfate-reducing bacteria in the presence of toluene as an electron donor and perchlorate ions as an electron acceptor was investigated. The efficiency of perchlorate ion utilization by sulfate-reducing bacteria Desulfotomaculum AR1 and D. desulfuricans Ya-11 was about $90 \%$. The effect of molybdenum on the reduction of perchlorate ions by Desulfotomaculum AR1 is shown in the paper. Immobilization of bacteria Desulfotomaculum AR1 and D. desulfuricans Ya-11 was carried out in 3\% agar and on wood chips. The ability of bacteria, immobilized on these media, to purify the aqueous medium from perchlorate ions was investigated. Reduction of perchlorate ions is more efficiently performed by cells of Desulfotomaculum AR1 and D. desulfuricans Ya-11 bacteria immobilized in agar than on wood chips. Sulfate-reducing bacteria Desulfotomaculum AR1 and D. desulfuricans Ya-11 are able to use perchlorate ions as electron acceptors, purifying the polluted aquatic environment from these pollutants.

Keywords: chlorine oxoanions; molybdenum; sulfidogenic activity; sulfate ion; perchlorate ion; sulfate-reducing bacteria; toluene.

\section{Introduction}

Problems of environment and food pollution by perchlorate ions are of worldwide relevance (Aribi et al., 2006). The perchlorate ion is a strong oxidizer which is mainly used as ammonium perchlorate $\left(\mathrm{NH}_{4} \mathrm{ClO}_{4}\right)$ to produce solid rocket propellant, rockets and explosives, military ammunition, fireworks, airbags and paints. Presence of perchlorate ions in water supplement systems and soil is also connected with the widespread usage of fertilizers, particularly, Chile saltpetre (Urbansky et al., 2001). Chlorine oxoanions can also be formed during the ozonation of chlorine treated drinking water (Sidiqqui, 1996). Perchlorate ions' content in the water of centralized drinking water supply systems must not exceed $0.01 \mathrm{mg} / \mathrm{dm}^{3}$, according to DSTU 7525 from the year 2014 . Perchlorate ions are also found in food, besides soil and the water environment (El Aribi et al., 2006). Perchlorate ions have a toxic effect on the human organism. Particularly, perchlorate ions competitively block iodine uptake by the thyroid gland and inhibit production of hormones, which can result in metabolic problems in adults and abnormal growth of children (Greer et al., 2002).

The high redox potential of chlorate and perchlorate ions $\left(\mathrm{E}_{\mathrm{o}}\left(\mathrm{ClO}_{3}{ }^{-}\right.\right.$ $\left./ \mathrm{Cl}^{-}\right)=1.03 \mathrm{~V} ; \mathrm{E}_{\mathrm{o}}\left(\mathrm{ClO}_{4}^{-} / \mathrm{Cl}^{-}\right)=1.287 \mathrm{~V}$ ) gives them the possibility to be ideal electron acceptors for the metabolism of microorganisms. Ability to reduce perchlorate ions has been described for Vibrio dechloraticans Cuznesove B-1168, Wolinella succinogenes HAP-1, Dechlorosoma suillum, Dechlorospirillum JB116 and other bacteria (Prata, 2007).
Bacteria can utilize $\mathrm{ClO}_{4}^{-}$as terminal acceptor of electrons. Not all species of chlorate-reducing bacteria can reduce perchlorate ions (Logan et al., 2001b). The effects of perchlorate ions on Bacillus subtilis bacteria, which are often the source of biological contamination on spacecraft, have been studied. Under the simultaneous influence of UV radiation and perchlorate ions, their toxicity is enhanced and a high level of bactericide effect is found as a result (Wadsworth \& Cockell, 2017).

Biological reduction of $\mathrm{ClO}_{4}^{-}$is a promising method of perchloratecontaining water purification (Prata, 2007). Bioreactors with the usage of microorganisms, able to reduce perchlorate ion to the non-toxic chloride ion at the presence of electron donor and medium for the growth of microorganisms, can be used for this purpose (Urbansky \& Shock, 1999).

Different environmental factors have influence on the microbial reduction of perchlorate ions, particularly, microelements, $\mathrm{pH}$, salts concentration, etc. (Logan et al., 2001a). The problem of biological purification of concentrated wastewater from $\mathrm{ClO}_{4}^{-}$exists, because microorganisms, able to reduce perchlorate ion at salinity over $2 \%$, are not isolated (Logan et al., 2001a).

The aim of research was to check the ability of sulfate-reducing bacteria Desulfovibrio desulfuricans Ya-11 and Desulfotomaculum AR1 to utilize perchlorate ion as the terminal electron acceptor and determine the influence of $\mathrm{ClO}_{4}^{-}$on sulfidogenic activity of microorganisms at different cultivation conditions, and also to determine the effectiveness of perchlorate ion utilization by immobilized cells of $D$. desulfuricans 
Ya-11 and Desulfotomaculum AR1 bacteria.

\section{Materials and methods}

Object of research - sulfate-reducing bacteria Desulfovibrio desulfuricans Ya-11, isolated from Yavoriv Lake (Peretyatko et al., 2006) and Desulfotomaculum AR1, isolated from Lviv wastewater purification system (Verkholiak \& Peretyatko, 2018). Bacteria were grown in Postgate $\mathrm{C}$ medium with the following content $(\mathrm{g} / \mathrm{L})$ : potassium dihydrophosphate -0.5 ; ammonium chloride -1.0 ; sodium sulfate -4.5 ; calcium chloride hexahydrate -0.06 ; magnesium sulfate heptahydrate 0.06 ; sodium lactate -6 ; yeast extract -1 ; ferrous sulfate heptahydrate 0.004; sodium citrate dihydrate $-0.3 ; \mathrm{pH} 7.6$ (Postgate, 1984), modified Postgate $\mathrm{C}$ medium (without sulfate ions) and modified Postgate $\mathrm{C}$ medium without sodium lactate with $2.6 \mathrm{~g} / \mathrm{L}$ of toluene. Perchlorate ion in the form of $\mathrm{NaClO}_{4}(0.12-1.00 \mathrm{mM})$ was added as electron acceptor to the medium without sulfate ion. $1-5 \mathrm{mM}$ of $\left(\mathrm{NH}_{4}\right)_{2} \mathrm{MoO}_{4}$ was added in the experiments on the effects of molybdenum on the reduction of perchlorate ion by sulfate-reducing bacteria.

Biomass was measured turbidimetrically using photoelectrocolorymeter KFK-3 ( $\lambda=340 \mathrm{~nm}, 3 \mathrm{~mm}$ cuvette). $\mathrm{SO}_{4}^{2-}$ content was measured turbidimetrically ( $\lambda=520 \mathrm{~nm}, 10 \mathrm{~mm}$ cuvette) after the sedimentation by barium chloride according to HOST 26426-85. Glycerol was used as the stabilizer of suspension. Hydrogen sulfide content was measured in culture liquid colorimetrically using $p$-aminodimethyl aniline dihydrochloride ( $\lambda=665 \mathrm{~nm}, 30 \mathrm{~mm}$ cuvette) (Sugiyama, 2002). Perchlorate ion was measured using permanganatometry (by titration of Mohr's salt residue with $0.1 \mathrm{n} \mathrm{KMnO}_{4}$ solution) (Petrashen, 1946).

Cultures of $D$. desulfuricans Ya-11 and Desulfotomaculum AR1 microorganisms were previously grown in modified Postgate $\mathrm{C}$ medium with perchlorate ions to perform immobilization. Immobilization of the studied strains was performed in 3\% agar. Immobilized bacteria were transferred to the column in the form of $1 \times 1 \mathrm{~cm}$ bars and poured with perchlorate solution in distilled water. Bacterial biomass was 0.1 and $1.0 \mathrm{~g} / \mathrm{L}$. Bacteria were also immobilized on the medium-sized $5 \mathrm{~g}$ wood chips, placed into a flask and poured with perchlorate solution in distilled water. Bacterial biomass was $0.1,0.4$ and $1.0 \mathrm{~g} / \mathrm{L}$. Perchlorate was added as different concentrations of $\mathrm{NaClO}_{4}$ in both cases.

Results are presented as $\mathrm{x} \pm \mathrm{m}$. Difference between control and experimental values was considered significant at $\mathrm{P}<0.05$. Single-factor dispersion analysis (ANOVA) and Tukey's test were used for statistical procession of results.

\section{Results}

We have studied the ability of sulfate-reducing bacteria Desulfotomaculum AR1 and D. desulfuricans Ya-11 to grow in medium with perchlorate ion as electron acceptor. Bacteria were cultivated in Postgate $\mathrm{C}$ media with sulfate ions (control), perchlorate ions, sulfate and perchlorate ions simultaneously for this purpose (Fig. 1).

Effectiveness of sulfate ion reduction by the studied bacteria is significantly high in control medium - approximately $60 \%$ in both bacterial strains, whereas it is $49 \%$ in Desulfotomaculum AR1 and $46 \%$ in D. desulfuricans Ya-11 at the presence of perchlorate ion (Table 1).

\section{Table 1}

Effect of perchlorate ions on the amount of reduced sulfate ions and hydrogen sulfide accumulation by Desulfotomaculum AR1 and $D$. desulfuricans Ya-11 during the growth in sodium lactate medium

\begin{tabular}{ccccc}
\hline & \multicolumn{4}{c}{ Cultivation medium } \\
\cline { 2 - 5 } Strain of bacteria & \multicolumn{3}{c}{ Lactate $+\mathrm{SO}_{4}{ }^{2-}$} & \multicolumn{2}{c}{ Lactate $+\mathrm{SO}_{4}{ }^{2-}+\mathrm{ClO}_{4}{ }^{-}$} \\
\cline { 2 - 5 } & \multicolumn{2}{c}{ concentration of sulfur-containing compounds, $\mathrm{mM}$} \\
\cline { 2 - 5 } & sulfate & hydrogen & sulfate & hydrogen \\
& ion & sulfide & ion & sulfide \\
\hline \multirow{2}{*}{ Desulfotomaculum AR1 } & \multirow{2}{*}{$16.15 \pm 0.26$} & $16.74 \pm$ & $13.77 \pm$ & $9.05 \pm$ \\
& & 0.90 & $0.39^{*}$ & $0.11^{* *}$ \\
D. desulfuricans Ya-11 & \multirow{2}{*}{$17.04 \pm 0.19$} & $13.58 \pm$ & $12.95 \pm$ & $12.11 \pm$ \\
& & 1.36 & $0.01^{* *}$ & 1.16 \\
\hline
\end{tabular}

Note: initial sulfate ion concentration $-28 \mathrm{mM} ; *_{-} \mathrm{P}<0.05$, **- $\mathrm{P}<0.01-$ probable changes of sulfate ion and hydrogen sulfide concentration (ANOVA).

Study of the ability of Desulfotomaculum AR1 and D. desulfuricans Ya-11 bacteria to grow using toluene (as electron donor) and perchlorate ions (as electron acceptor) showed the following results. Growth of Desulfotomaculum AR1 and D. desulfuricans Ya-11 bacteria in modified Postgate $\mathrm{C}$ media with toluene and sulfate ions, perchlorate ions, sulfate and perchlorate ions is almost equal in all media: $D$. desulfuricans Ya-11 biomass was approximately $1.3 \mathrm{~g} / \mathrm{L}$ (Fig. 2b), Desulfotomaculum AR1 biomass - near 1 g/L (Fig. 2a).
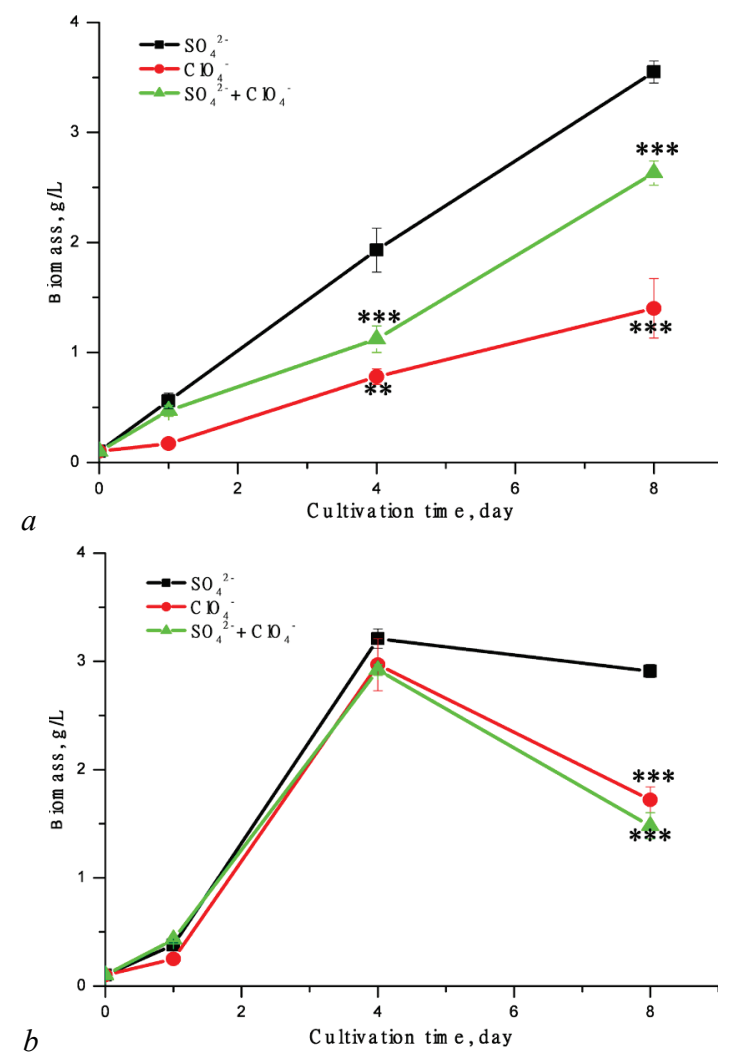

Fig. 1. Biomass accumulation by Desulfotomaculum AR1 $(a)$ and D. desulfuricans Ya-11 (b) in media with sodium lactate and various electron acceptors $(\mathrm{x} \pm \mathrm{m}, \mathrm{n}=3)$; ** $-\mathrm{P}<0.01$, *** $-\mathrm{P}<0.001-$ probable biomass changes compared to control (Tukey test)

Effectiveness of sulfate ion reduction during growth of bacteria in medium with toluene was approximately $16 \%$ in Desulfotomaculum AR1 and $20 \%$ in D. desulfuricans Ya-11 (Table 2).

\section{Table 2}

Effect of perchlorate ions on the amount of reduced sulfate ions and hydrogen sulphide accumulation by Desulfotomaculum AR1 and $D$. desulfuricans Ya-11 during the growth in sodium lactate medium

\begin{tabular}{ccccc}
\hline & \multicolumn{4}{c}{ Cultivation medium } \\
\cline { 2 - 5 } Strain of bacteria & \multicolumn{3}{c}{ Toluene $+\mathrm{SO}_{4}^{2-}$} & Toluene $+\mathrm{SO}_{4}{ }^{2-}+\mathrm{ClO}_{4}{ }^{-}$ \\
\cline { 2 - 5 } & \multicolumn{2}{c}{ Concentration of sulfur-containing compounds, $\mathrm{mM}$} \\
\cline { 2 - 5 } & sulfate & hydrogen & sulfate & hydrogen \\
& ion & sulfide & ion & sulfide \\
\hline \multirow{2}{*}{ Desulfotomaculum $\mathrm{AR} 1$} & $4.79 \pm 0.08$ & $2.49 \pm 0.20$ & $4.02 \pm$ & $1.49 \pm$ \\
& & & $0.07^{*}$ & $0.14^{*}$ \\
D. desulfuricans Ya-11 & $5.79 \pm 0.13$ & $2.01 \pm 0.10$ & $3.91 \pm 0.19^{*}$ & $1.09 \pm 0.02^{*}$ \\
& & & $*$ & $*$ \\
\hline
\end{tabular}

Note: initial sulfate ion concentration $-28 \mathrm{mM}$; $-\mathrm{P}<0.05, * *_{-} \mathrm{P}<0.01-$ probable changes of sulfate ion and hydrogen sulfide concentration, compared to control (ANOVA).

Perchlorate ions were practically absent in the medium during growth of sulfate-reducing bacteria Desulfotomaculum AR1 and D. desulfuricans Ya-11 in Postgate C medium with $\mathrm{ClO}_{4}^{-}$(Fig. 3). Sulfate-reducing bac- 
teria Desulfotomaculum AR1 were cultivated in sulfate-free Postgate C medium with $0.1,1.0$ and $5.0 \mathrm{mM}$ of $\mathrm{MoO}_{4}^{2-}$ to study effects of molybdenum on their growth. Initial concentration of perchlorate ions was 1 $\mathrm{mM}$. Medium without $\mathrm{MoO}_{4}^{2-}$ was used as a control. The process of perchlorate ion reduction increased by almost $15 \%$ at $\mathrm{MoO}_{4}{ }^{2-}$ concentration 0.1 and $1.0 \mathrm{mM}$ (Fig. 4). Bacteria reduced less $\mathrm{ClO}_{4}^{-}$at molybdenum concentration $5 \mathrm{mM}$, than in control.

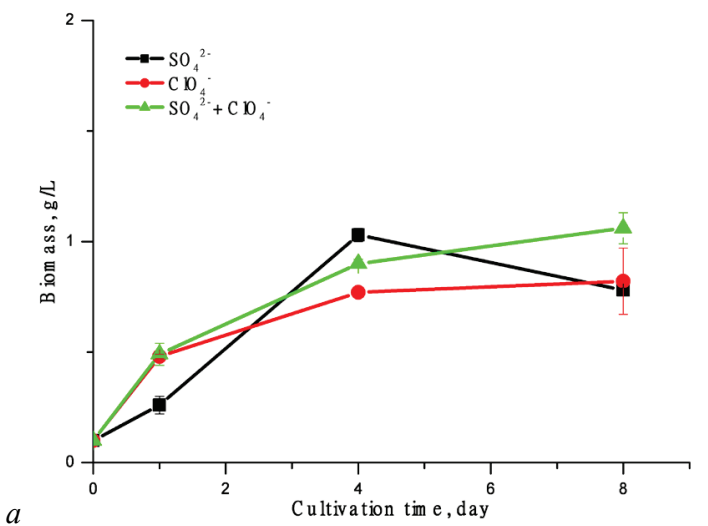

$a$

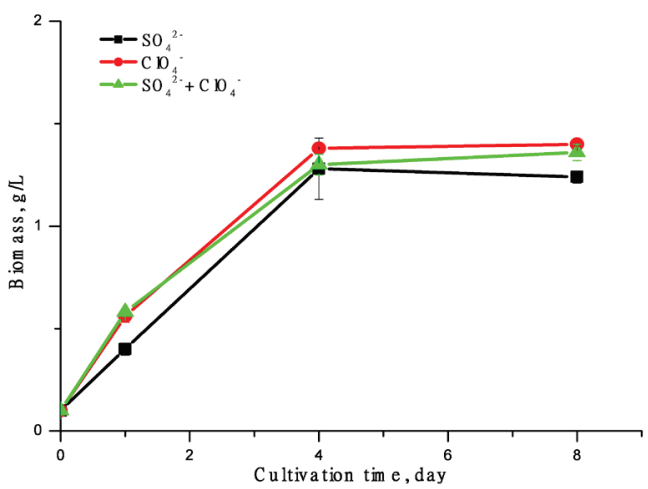

Fig. 2. Biomass accumulation by Desulfotomaculum AR1 (a) and $D$. desulfuricans Ya-11 $(b)$ in media with toluene and different electron acceptors $(\mathrm{x} \pm \mathrm{m}, \mathrm{n}=3)$

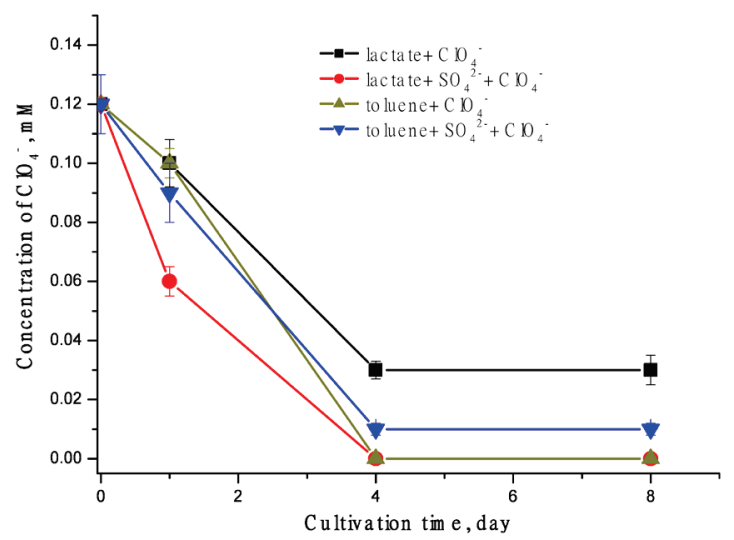

$a$

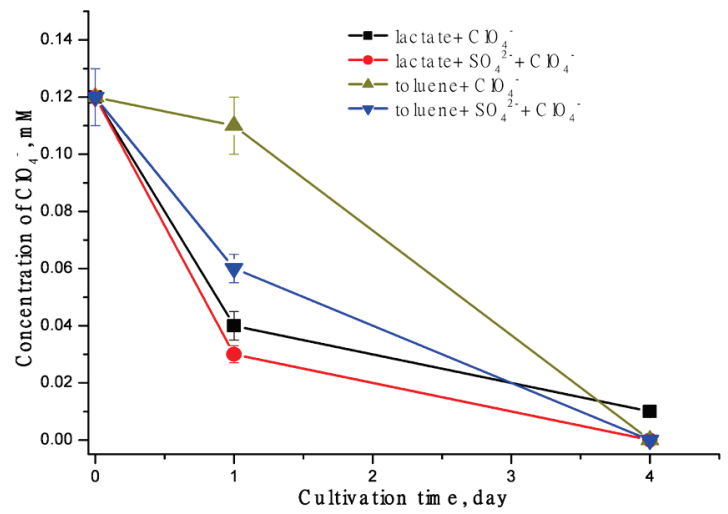

Fig. 3. Utilization of perchlorate ions as electron acceptors by Desulfotomaculum AR1 (a) and D. desulfuricans Ya-11 (b) in media with different carbon sources $(\mathrm{x} \pm \mathrm{m}, \mathrm{n}=3)$

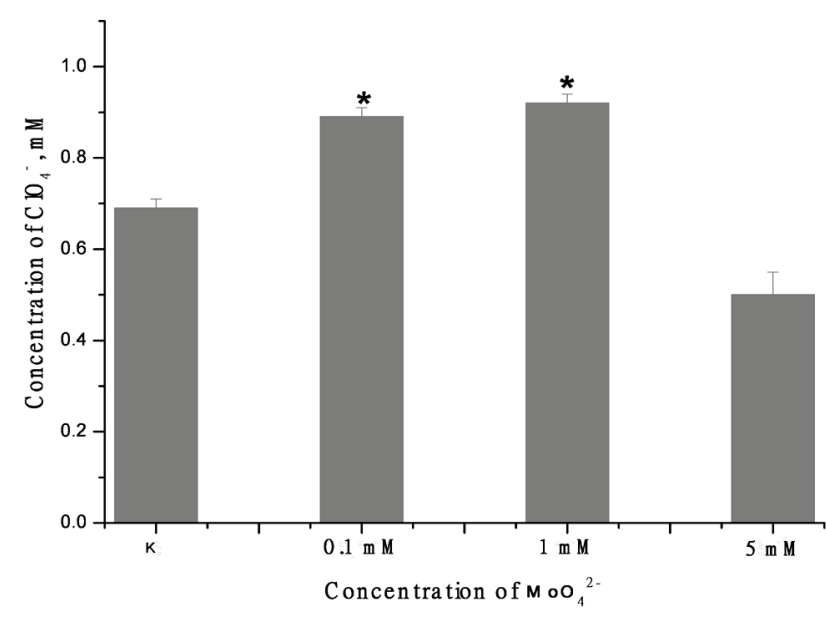

Fig. 4. The effect of molybdenum on the reduction of perchlorate ions by bacteria Desulfotomaculum AR1: * $-\mathrm{P}<0.05$ - significant changes in $\mathrm{ClO}_{4}^{-}$concentration compared to control (ANOVA)

We have checked the ability of the studied agar-immobilized bacteria to purify polluted water from perchlorate ions. Full removal of perchlorate ions by Desulfotomaculum AR1 bacteria at concentration $1 \mathrm{~g} / \mathrm{L}$ was found in $24 \mathrm{~h}$, and in $76 \mathrm{~h}$ at initial concentration of cells $0.1 \mathrm{~g} / \mathrm{L}$ (Fig. 5a). D. desulfuricans Ya-11 bacteria at concentration $1 \mathrm{~g} / \mathrm{L}$ fully removed perchlorate ions from solution in $48 \mathrm{~h}$ of cultivation. Purification from perchlorate ions by cells concentration $0.1 \mathrm{~g} / \mathrm{L}$ to $0.02 \mathrm{mM}$ occurred in $48 \mathrm{~h}$ and perchlorate ion concentration did not further decrease (Fig. $5 \mathrm{~b}$ ).
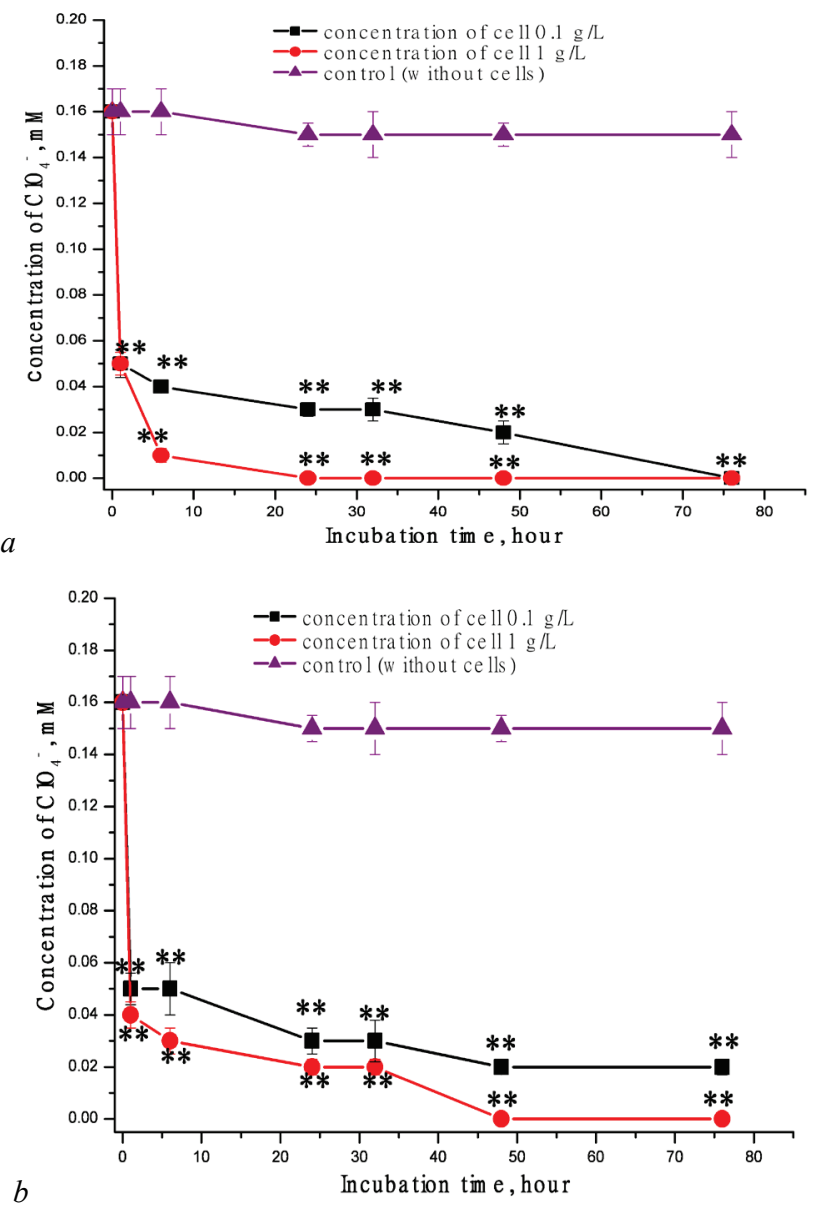

Fig. 5. Utilization of perchlorate ions as electron acceptor by Desulfotomaculum AR1 ( $a$ ) and $D$. desulfuricans Ya-11 (b) bacteria immobilized in agar (control - cell-free agar): 


\section{** $-\mathrm{P}<0.01$ - significant changes in $\mathrm{ClO}_{4}^{-}$concentration compared to control (ANOVA)}

In Figure 6, the results are presented of experiments on reduction of $\mathrm{ClO}_{4}^{-}$by immobilized on wooden chips cells of bacteria Desulfotomaculum $\mathrm{AR} 1$ and $D$. desulfuricans $\mathrm{Ya}-11 . \mathrm{ClO}_{4}^{-}$concentration decreased from 0.07 to $0.02 \mathrm{mM}$ in $30 \mathrm{~h}$ and did not further decrease in the case of incubation of $0.1 \mathrm{~g} / \mathrm{L}$ of Desulfotomaculum AR1 cells, and to $0.03 \mathrm{mM}$ in $30 \mathrm{~h}$ and to $0.02 \mathrm{mM}$ in $74 \mathrm{~h}$ in the case of incubation of $D$. desulfuricans Ya-11 cells (Fig. 6a). Desulfotomaculum AR1 bacteria reduced $0.09 \mathrm{mM}$ of $\mathrm{ClO}_{4}^{-}$at concentration of cells $0.4 \mathrm{~g} / \mathrm{L}$, whereas $D$. desulfuricans Ya-11 bacteria $-0.06 \mathrm{mM}$ (Fig. $6 \mathrm{~b}$ ). The studied cultures of microorganisms reduced $0.03 \mathrm{mM}$ of perchlorate ions more at concentration $1.0 \mathrm{~g} / \mathrm{L}$ than at $0.4 \mathrm{~g} / \mathrm{L}$

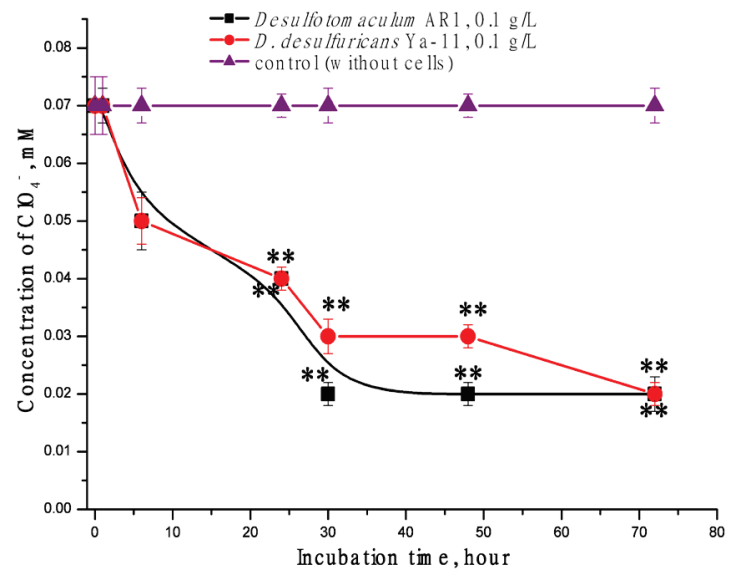

$a$

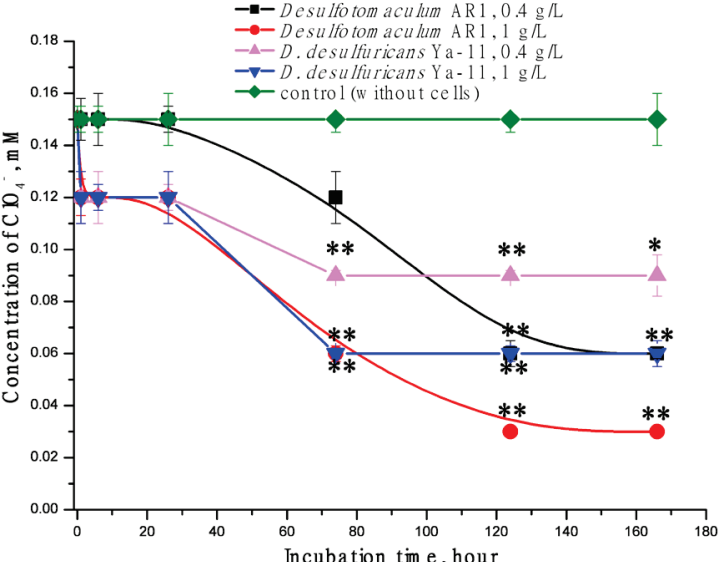

Fig. 6. Reduction of perchlorate ions by immobilized on wooden chips cells of bacteria Desulfotomaculum AR1 and

D. desulfuricans Ya-11 at a concentration $0.1 \mathrm{~g} / \mathrm{L}(a)$ and $0.4-1.0 \mathrm{~g} / \mathrm{L}$

(b); ${ }^{*}-\mathrm{P}<0.05,{ }^{*}{ }_{-} \mathrm{P}<0.01$ - significant changes in $\mathrm{ClO}_{4}$ concentration compared to control (ANOVA)

Effectiveness of perchlorate ion utilization by agar-immobilized Desulfotomaculum AR1 cells $(0.1 \mathrm{~g} / \mathrm{L})$ was $81 \%$ in $24 \mathrm{~h}$, while by suspension cells (initial biomass $-0.1,0.2 \mathrm{~g} / \mathrm{L}$ in $24 \mathrm{~h}$ ) $-17 \%$ (Fig. 7a).

Perchlorate ion content also decreased by $81 \%$ in $24 \mathrm{~h}$ with the usage of agar-immobilized $D$. desulfuricans Ya-11 bacteria (biomass $0.1 \mathrm{~g} / \mathrm{L}$ ) and by $67 \%$ by suspension cells, but the amount of cells increased three times $(0.1-0.3 \mathrm{~g} / \mathrm{L})$ in one day in this case (Fig. $7 \mathrm{~b})$. Such effectiveness of perchlorate ion utilization was not found in the case of immobilization of bacteria on wooden chips. Process of $\mathrm{ClO}_{4}^{-}$reduction was slower and, as a consequence, less effective at these conditions.

\section{Discussion}

Usage of biological methods of water purification from perchlorate ions is most often connected with the ability of microorganisms to reduce $\mathrm{ClO}_{4}{ }^{-}$to $\mathrm{Cl}^{-}$using electron donors - different organic substrates - alcohols, carbonic acids, simple fatty acins, etc. (Nerenberg et al., 2002;
Nerenberg et al., 2006; Prata, 2007). We have checked the ability to purify polluted water from perchlorate ions using Desulfotomaculum AR1 and $D$. desulfuricans Ya-11 bacteria. Simslar research was conducted by Smirnova (2010) using bacteria, isolated from different ecological niches, most of which had low oxygen concentration, particularly from places of natural enrichment (wastewater of plants and dumps), etc. The best growth of studied bacterial strains was found in control medium, whereas Desulfotomaculum AR1 bacteria grew a little bit worse in the medium with perchlorate ion than D. desulfuricans Ya-11 (Fig. 1a, b). Presence of both electron acceptors - sulfate and perchlorate ions resulted in accumulation of approximately $2.5 \mathrm{~g} / \mathrm{L}$ of biomass, which is twice as high as biomass of Desulfotomaculum AR1 bacteria in the medium with $\mathrm{ClO}_{4}^{-}$. D. desulfuricans Ya-11 grew equally in media with $\mathrm{ClO}_{4}^{-}$and both $\mathrm{SO}_{4}{ }^{2-}$ and $\mathrm{ClO}_{4}{ }^{-}$. Presence of perchlorate ions in the medium somewhat inhibited sulfate ion reduction by Desulfotomaculum AR1 and D. desulfuricans Ya-11 bacteria (Table 1).

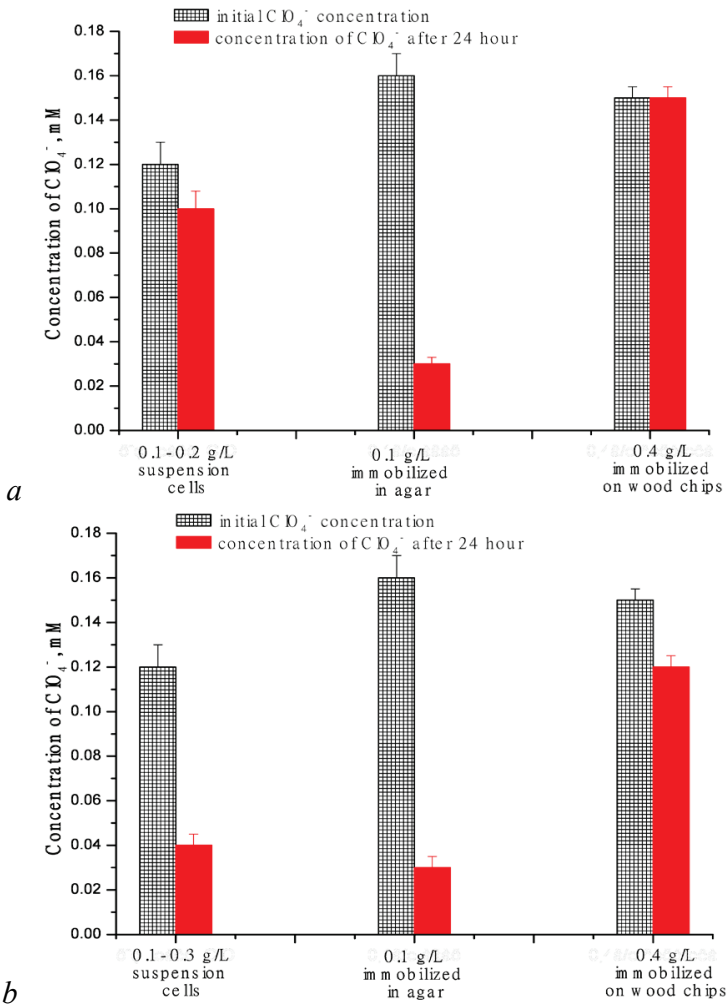

Fig. 7. Utilization of $\mathrm{ClO}_{4}^{-}$as an electron acceptor by immobilized and suspension cells of bacteria Desulfotomaculum AR1 $(a)$ and $D$. desulfuricans Ya-11 (b)

We have shown the ability of Desulfotomaculum AR1 and D. desulfuricans Ya-11 bacteria to utilize toluene as a carbon and energy source in our previous works (Verkholiak \& Peretyatko, 2019). Growth of Desulfotomaculum AR1 and D. desulfuricans Ya-11 bacteria in the medium with toluene is twice as low as in the control medium with sodium lactate (Fig. 1, 2). Effectiveness of sulfate ion reduction during the growth of Desulfotomaculum AR1 and D. desulfuricans Ya-11 bacteria in the medium with toluene is considerably lower than in the medium with sodium lactate (Table 1). Presence of perchlorate ions caused 1.5fold inhibition of reduction of $\mathrm{SO}_{4}{ }^{2-}$ by $D$. desulfuricans Ya-11 bacteria during their growth in the medium with toluene (Table 2). Effectiveness of perchlorate ion utilization during the growth of studied strains of bacteria in Postgate $\mathrm{C}$ medium with sodium lactate/toluene and with/ without sulfate ions was quite high - near $90 \%$.

A number of factors have influence on the process of bacterial reduction of perchlorate ions $-\mathrm{pH}$, salts concentration, presence of microelements and other electron acceptors (Prata, 2007). Neutral pH is optimal for most perchlorate-reducing bacteria, oxygen and nitrate ions can inhibit the reduction of perchlorate ions (Chaudhuri et al., 2002; Prata, 2007). Molecular studies of the gene which codes perchlorate 
reductase showed that its expression is regulated by the presence of atmospheric oxygen (Bender et al., 2005). It is known that reduction of perchlorate ions depends on the availability of molybdenum compounds. Molecular studies of genetic systems, connected with the reduction of perchlorate ions, indicate the presence of molybdenum dependent chaperone, connected with genes, coding synthesis of chlorite dismutase (EC 1.13.11.49) and perchlorate reductase (EC 1.97.1.1) enzymes of perchlorate ion reduction in Dechloromonas aromatica RCB and Pseudomonas sp. PK (Bender et al., 2002). $\mathrm{MoO}_{4}^{2-}$ at concentrations 0.1 and $1.0 \mathrm{mM}$ had a positive effect on the process of perchlorate ion reduction, whereas some inhibitory effect on the reduction of $\mathrm{ClO}_{4}^{-}$in Desulfotomaculum AR1 bacteria was found at molybdenum concentration $5 \mathrm{mM}$ (Fig. 4).

Immobilized cells of microorganisms have a number of advantages over suspension cells, particularly, higher activity and stability, and also economic effectiveness. Immobilization enables the creation of non-stop automated processes, durable functioning of polyenzyme systems, independent from exogenic factors (Starovoitova, 2012). That is why we decided to check the ability of agar-immobilized Desulfotomaculum AR1 and D. desulfuricans Ya-11 bacteria to utilize perchlorate ions (Fig. 5). A high amount of waste, which can be further used, particularly, with the aim of biological purification, is produced in the process of wood treatment. Immobilization of microorganisms' cells on the wood chips was used to obtain vinegar more than 150 years ago (Melnyk et al., 2019). We have shown the suitability of usage of wooden chips-immobilized sulfate-reducing bacteria to purify water, polluted by perchlorate ions (Fig. 6). We can conclude from the obtained results that perchlorate ion reduction is performed somewhat faster by agar-immobilized Desulfotomaculum AR1 and D. desulfuricans Ya-11 bacteria cells, than by such cells immobilized by wooden chips, but agar is a less economically profitable substrate than wooden chips. Reduction of perchlorate ion by wooden chipsimmobilized Desulfotomaculum AR1 bacteria is performed a little better than by $D$. desulfuricans Ya-11. Results of comparison of effectiveness of perchlorate ion reduction by suspension, agar- and wooden chips-immobilized Desulfotomaculum AR1 and D. desulfuricans Ya-11 bacteria cells are shown in Figure 7. We can conclude according to the obtained results of the study of perchlorate ion utilization by sulfate-reducing bacteria that immobilized Desulfotomaculum AR1 and D. desulfuricans Ya-11 bacteria cells purify perchlorate-containing water from $\mathrm{ClO}_{4}^{-}$more effectively than suspension ones.

Environmental pollution by oxygen-containing chlorine compounds is a problem that requires solution. Sulfate-reducing bacteria Desulfotomaculum $\mathrm{AR} 1$ and $D$. desulfuricans Ya-11 are able to utilize perchlorate ions as electron acceptors in their metabolism, decreasing their content in polluted water. Immobilization of Desulfotomaculum AR1 and D. desulfuricans Ya-11 bacteria cells shows the suitability of their usage in methods of purification of water polluted by perchlorate ions.

\section{Conclusions}

The high redox potential of the perchlorate ion causes its utilization as an electron acceptor by microorganisms. Usage of anaerobic bacteria with the aim of purification of water polluted by perchlorate ions is more suitable than that of aerobic ones because oxygen inhibits perchlorate reduction in bacteria. Environmental factors have influence on the biological reduction of perchlorate ions, particularly, molybdenum, which had a positive effect on the process of perchlorate reduction in Desulfotomaculum AR1 bacteria at concentrations 0.1-1.0 mM. Organic compounds, particularly, aromatic, for example, toluene, are present in water, besides inorganic ones. Desulfotomaculum AR1 and D. desulfuricans Ya-11 bacteria are able to grow in media, utilizing aromatic compounds as the sole energy source and electron donor and perchlorate ions as electron acceptors. Effectiveness of perchlorate ions utilization was near $90 \%$. Biological purification of environments polluted by toluene, sulfate and perchlorate ions using sulfate-reducing bacteria is safe and promising method of bioremediation. Immobilization of sulfate-reducing bacteria strains is suitable in the conditions of purification of polluted environments from perchlorate ions.

\section{References}

Aribi, E. H., Le Blanc, Y. J. C., Antonsen, S., \& Sakuma, T. (2006). Analysis of perchlorate in foods and beverages by ion chromatography coupled with tandem mass spectrometry (IC-ESI-MS/MS). Analytica Chimica Acta, 567(1), $39-47$.

Bender, K. S., O’Connor, S. M., Chakraborty, R., Coates, J. D., \& Achenbach, L. A. (2002). Sequencing and transcriptional analysis of the chlorite dismutase gene of Dechloromonas agitata and its use as a metabolic probe. Applied and Environmental Microbiology, 68, 4820-4826.

Bender, K. S., Shang, C., Chakraborty, R., Belchik, S. M., Coates, J. D., \& Achenbach, L. A. (2005). Identification, characterization, and classification of genes encoding perchlorate reductase. Journal of Bacteriology, 187(15), 5090-5096.

Chaudhuri, S. K., O'Connor, S. M., Gustavson, R. L., Achenbach, L. A., \& Coates, J. D. (2002). Environmental factors that control microbial perchlorate reduction. Applied and Environmental Microbiology, 68(9), 4425-4430.

Greer, M. A., Goodman, G., Pleus, R. C., \& Greer, S. E. (2002). Health effects assessment for environmental perchlorate contamination: The dose response for inhibition of thyroidal radioiodine uptake in humans. Environmental Health Perspectives, 110, 927-937.

Logan, B. E., Wu, J., \& Unz, R. F. (2001a). Biological perchlorate reduction in highsalinity solutions. Water Research, 35, 3034-3038.

Logan, B. E., Zhang, H., Mulvaney, P., Milner, M. G., Head, I. M., \& Unz, R. F. (2001b). Kinetics of perchlorate- and chlorate-respiring bacteria. Applied and Environmental Microbiology, 67, 2499-2506.

Melnyk, V. M., Ruzhynska, L. I., \& Vorobiova, O. V. (2019). Analiz isnuiuchykh bioreaktoriv z immobilizovanymy mikroorhanizmamy [Analysis of existing bioreactors with immobilized microorganisms]. Komunalne Hospodarstvo Mist, 149, 51-57 (in Ukrainian).

Nerenberg, R., Kawagoshi, Y., \& Rittmann, B. E. (2006). Kinetics of a hydrogenoxidizing, perchlorate-reducing bacterium. Water Research, 40(17), 3290-3296.

Nerenberg, R., Rittmann, B. E., \& Najm, I. (2002). Perchlorate reduction in a hydrogen-based membrane-biofilm reactor. Journal American Water Works Association, 94(11), 103-114.

Peretyatko, T. B., Hnatush, S. O., \& Gudz, S. P. (2006). Sulfatvidnovliuvalni bakterii Yavorivskoho sirkovoho rodovyshcha [Sulfate-reducing bacteria from Yavoriv storage lake]. Mikrobiolohichnyi Zhurnal, 68(5), 84-91 (in Ukrainian).

Petrashen, V. I. (1946). Ob'emnyi analiz [Volumetric analysis]. Goskhimizdat, Moscow (in Russian).

Postgate, J. R. (1984). The sulfate-reducing bacteria. 2nd ed. Cambridge University Press, Cambridge.

Prata, F. C. P. (2007). Perchlorate and chlorate degradation by two organisms isolated from wastewater. Microbial identification and kinetics. Instituto Superior Technico, Universidade de Lisboa, Lisboa.

Siddiqui, M. (1996). Chlorine-ozone interactions: Formation of chlorate. Water Research, 30(9), 2160-2170

Smirnova, G. F. (2010). Osobennosti metabolizma bakteriy, vosstanavlivayuschih hloraty i perhloraty [Metabolism peculiarities of bacteria restoring chlorates and perchlorates]. Mikrobiolohichnyi Zhurnal, 72(4), 22-28 (in Russian).

Starovoitova, S. O. (2012). Suchasni aspekty tekhnolohii immobilizovanykh probiotykiv [Modern aspects of technology of immobilized probiotics]. Biotechnologia, 5(4), 9-20 (in Ukrainian).

Sugiyama, M. (2002). Incassignee. Reagent composition for measuring hydrogen sulfide and method for measuring hydrogen sulfide. United States Patent $6,340,596$ B1. 2002 Jan 22.

Urbansky, E. T., \& Shock, M. R. (1999). Issues in managing the risks associated with perchlorate in drinking water. Journal of Environmental Management, 56(2), 79-95.

Urbansky, E. T., Brown, S. K., Magnuson, M. L., \& Kelty, C. A. (2001). Perchlorate levels in samples of sodium nitrate fertilizer derived from Chilean caliche. Environmental Pollution, 112(3), 299-302.

Verkholiak, N. S., \& Peretyatko, T. B. (2018). Morfofiziolohichni vlastyvosti sulfatvidnovliuvalnykh bakterii, vydilenykh iz systemy ochyshchennia stichnykh vod $\mathrm{m}$. Lvova [Morphophysiological properties of sulfate-reducing bacteria isolated from the system of Lviv wastewater treatment]. Microbology and Biotechnology, 4, 19-29 (in Ukrainian).

Verkholiak, N. S., \& Peretyatko, T. B. (2019). Destruktsiia toluenu ta ksylenu sulfatvidnovliuvalnymy bakteriiamy [Destruction of toluene and xylene by sulfate-reducing bacteria]. Ecology and Noospherology, 30(2), 95-100 (in Ukrainian).

Wadsworth, J., \& Cockell, C. S. (2017). Perchlorates on Mars enhance the bacteriocidal effects of UV light. Scientific Reports, 7(4662), 1-8. 